RESEARCH NOTE

\section{Rapid Detection of Respiratory Syncytial Virus by Indirect Immunofluorescence in Infants Hospitalized with Acute Respiratory Disease}

\section{Angel Goyenechea, Rafael Razon, Clara Savon ${ }^{+}$, Angel Valdivia, Danay Chacon, Luis Sarmiento}

\author{
Instituto de Medicina Tropical "Pedro Kourí", \\ Autopista Novia del Mediodia Km 6, \\ Apartado Postal 601, Marianao 13, Ciudad de la \\ Habana, Cuba
}

Key words: respiratory syncytial virus - viral infection - Cuba

Respiratory syncytial virus (RSV) is well recognized as the single most important pathogen accounting for acute viral infections of lower respiratory tract in infants and young children. Outbreaks of RSV infections occur each year in winter and early spring (L Pednealut et al. $1994 \mathrm{~J} \mathrm{Clin}$ Microbiol 32: 2861-2864). In Cuba, acute respiratory diseases (ARD) constitute a major problem of health, and are the first cause of morbidity and occupy the first place of mortality in the context of all the infectious diseases, in all groups of age. Since October 1994 an increase of medical attention and admission due to ARD and bronchiolitis were noticed in children below one year old in pediatrics hospitals in Havana City.

This report provides the data of 70 infants hospitalized from October to December 1994 in the respiratory ward of the "William Soler" Paediatric
Hospital in Havana City during an outbreak of ARD having a major clinical diagnosis of bronchiolitis.

Nasopharyngeal swab specimens were obtained from 70 infants (0-1 year old) who had been admitted with ARD, all specimens were taken within the first $24 \mathrm{hr}$ of admission until four days of onset of disease. Specimens were placed in vials containing viral transport medium (Hanks Lactoalbumin solution plus penicillin $100 \mathrm{U} / \mathrm{ml}$; amphotericin B $5 \mu \mathrm{g} / \mathrm{ml}$; streptomycin $100 \mu \mathrm{g} / \mathrm{ml}$ ), and transported, under refrigeration to the laboratory. Indirect immunofluorescence (IIF) test was performed using a commercial kit of monoclonal antibodies (Chemicon International Inc.,CA, USA) for rapid diagnosis of respiratory viruses (Influenza A, Influenza B, Parinfluenza 1, Parainfluenza 2, Parainfluenza 3, Adenovirus and RSV, kindly supplied by Dr Nancy Cox, CDC, Atlanta, USA. All specimens were evaluated according to the manufactures' instructions.

From the 70 specimens examined by the IIF test $32(45.7 \%)$ were positive, RSV was the most frequent agent detected in 27 cases $(38.6 \%)$ and in $5(7.1 \%)$ cases the following viruses were detected, two influenza A, one influenza B, one parainfluenza 1 and one parainfluenza 3.

Among the 52 cases admitted with the clinical diagnosis of bronchiolitis, the only virus detected was RSV; nevertheless, this figure didn 't show statistical difference $(p>0.05)$ when it is compared with that for patients not having this clinical condition (Table).

It's well known that RSV is responsible for $50 \%$ of all cases of bronchiolitis among infants of six weeks to six months of age. The morbidity is considerable, and RSV infections in this age group often require hospitalization (MC Smith et al. 1991 J Clin Microbiol 29: 463-465). In our country, epidemics outbreaks of RSV usuallly occur in short (7 to 12 months) or in large (12 to 16 months) periods during autum, winter and spring (A Goyenechea et al. 1994 Rev Cub Med Trop 46: 79-85), similary to what has been reported by other authors.

In summary, we can conclude that RSV was the main etiological agent in this outbreak. 


\section{TABLE}

Occurrence of respiratory viruses among hospitalized infants during an outbreak of acute respiratory disease (ARD) in Havana, Cuba, from October to December 1994

\begin{tabular}{lcccccccc}
\hline $\begin{array}{l}\text { Clinical } \\
\text { diagnosis }\end{array}$ & $\begin{array}{c}\text { No. of } \\
\text { cases }\end{array}$ & RSV(+) & Inf. A(+) & Inf. B(+) & Pi-1 (+) & Pi-3 (+) & Total & $\%$ \\
\hline $\begin{array}{l}\text { Bronchiolitis } \\
\text { Other ARD }\end{array}$ & 52 & 21 & 0 & 0 & 0 & 0 & 21 & 40.4 \\
\hline Total & 18 & 6 & 2 & 1 & 1 & 1 & 11 & 61.1 \\
\hline
\end{tabular}

RSV- respiratory syncytial virus, Inf. A- influenza A, Inf. B- influenza B, P i-1- parainflluenza 1, P i-3 parainflluenza 3 . 